\title{
Foreign workers: On the other side of gendered, racial, political and ethical borders
}

\section{Rutvica Andrijasevic[GQ: 1]}

University of Bristol, UK

\section{Carl Rhodes}

University of Technology Sydney, Australia

\section{Kyoung-Hee Yu}

UNSW, Australia

\begin{abstract}
While political issues related to migration and work have been explored in great detail from the perspective of, inter alia, industrial relations, international business, economics and of course migration studies itself, they have been notably absent from any real consideration at all in organization studies. This appears as an almost wilful omission of one of the most pressing political issues facing the post-globalized world, as well as one in which work organizations are centrally implicated. This article, and the Special Issue which it introduces, explores how what it means to be a 'foreign' worker is deeply influenced by and connected to sexuality, gender, politics and ethics. We consider considered individual differences, context-specific experiences and dynamic processes through which the sexed, gendered and classed category of the foreign worker is constructed, enacted and resisted. We find that class, race and gender serve to shape a sense of foreignness that is central to the meaning and experience of work. The machinations of power are never far away, as people's differences come to be used as an axis of actual and potential oppression, coercion and exploitation
\end{abstract}

\section{Keywords}

Ethics, foreign workers, gender, migration, politics, race, work 
The conditions of the contemporary economy - the expansion of mass transport technology and the liberalization of global labour markets - has meant a vast expansion of mobility. The most recent figures estimate there to be 258 million international migrants worldwide (United Nations (UN), 2017). We focus in this Special Issue on foreign workers, as the largest and growing impetus for migration is work: of international migrants, 164 million are employed or seeking work (ILO Labour Migration Branch, 2018). This idea for a Special Issue on foreign workers first arose in 2015 with a chance discussion across different research interests and theoretical inspirations. For Rutvica, trained in Women's Studies and with a long-standing research agenda and political activism on migration, this has involved dealing with the tension between gender, migration, and citizenship rights as well as how cross-border mobility has come to occupy a vital place in political struggle over labour market access. Carl's research has drawn on poststructural theory and organization studies to explore the relationship between ethics and politics in business organizations; related to this issue is a concern with intersectional justice and equality in organizations as pivotal elements of democratic politics as well as with the importance of justice as it relates to work and commerce. For Kyoung-Hee with her research training in Work and Employment Studies, and with expertise in the relationship between organizational, institutional and political change, this involved addressing the impact of international migration on individual migrants and their careers, collective action and union revitalization, as well as implications for diversity and inclusion in organizations.

It is in the juncture of these interests and disciplinary backgrounds that the main theme of this Special Issue was formulated in terms of how what it means to be a 'foreign' worker is deeply influenced by and connected to sexuality, gender, politics and ethics. We decided to use the word 'foreign' as a deliberately provocative label to conjure up the image of the 'othered' migrant worker. We connected this with the idea of 'border' as a means of examining how this othering, as an ethically laden cultural and political process, was signified by the movement across geographical borders. This led us to pose the following questions as a means of elaborating our interests. What does it mean to be a foreign worker in today's global economy? How does being foreign intersect with assumptions about gender and sexuality? What are the ethical and political ramifications of this for individuals, organizations, labour markets and the state? These questions were very much politically motivated, arising as they do from a long history of the exclusion, abuse and discrimination of foreign workers, especially those who are women, working class, people of colour and sexual minorities. Cast as a double 'other', when it comes to Western countries foreign workers who do not fit with white male heteronormative expectations occupy a special ethical position, one where they are, as the etymological trace back to the Latin foranus suggests, on the outside.

While political issues related to migration and work have been explored in great detail from the perspective of, inter alia, industrial relations, international business, economics and of course migration studies itself, they have been notably absent from any real consideration at all in organization studies (for notable exceptions see Essers and Benschop, 2007; Yu, 2014a). This appeared to us to be an almost wilful omission of one of the most pressing political issues facing the postglobalized world, as well as one in which work organizations are centrally implicated. This was exacerbated when, in the midst of our work on this Special Issue, on 23 June 2016 the citizens of the United Kingdom voted to leave the European Union. In what came to be called Brexit, the fear of immigration loomed heavy as a motivating force for many of the voters, as did the spectre of racism and white supremacy. Things became only more pronounced a year later when US President Donald Trump announced a travel ban against citizens of a nominated list of largely Muslim countries. By his own admission, the purpose of this was that of 'preventing Muslim immigration'. As we write the shutdown of the US government over the funding of a border wall with Mexico, demonstrates yet again the connection between geographical borders and the ethical castigation of those who are deemed foreign. 
While the politics of migration are being played out on the world stage and the emergence of populist governments has served to exclude and alienate foreigners as well as ethnic and sexual minorities, the discipline of Organization Studies had little to say on the topic. Interest is still be current in other disciplines, however, with two other Special Issues commissioned by business related journals shortly after ours on the topic of migrant workers. One, whose call for papers was entitled 'Migration and Work', was in the Journal of Industrial Relations and had a distinct focus on policy and regulation, among other things. A second, entitled 'Global Migrants: Understanding the Implications for International Business and Management' and issued by the Journal of World Business, stressed the potential for global organizations to harness migrant skills and knowledge. Together these Special Issues represent specific areas of concern surrounding labour migration as one of the grand challenges in today's society. What this still evinces, however, is a need for this to be questioned and supplemented by the more critical approach that we have taken with this Special Issue.

Brexit and Trump's travel ban shocked many for their blatant association with populist antiimmigration politics and racial vilification. Yet, the 'othering' of foreign workers did not, of course, start there; it has long been part of institutionalized structures and practices. It is also the case that employment regulations, work practices and the management of organizations are all influenced by assumptions and norms about sexuality, gender, race and nationality (Acker, 2006). This has significant ramifications for the lived experience of foreign workers (Essers et al., 2010), for the potential for their engagement in diverse organizing and resistance efforts (Alberti et al., 2013; Yu, 2014a), and for the workplace as a 'cultural battleground' (Yu, in press).

The ethical implications of this relate to differences in how people are treated, the rights they are granted, the forms of discrimination they face and the freedoms that are open to them. Such differences are organized on both sexual and gendered grounds. This presents a clear risk that foreign workers, women, and lesbian, gay, bisexual, transgender and intersex (LGBTI) people can be exposed to ethical subjugation on account of their foreignness. Also at risk is an undermining of their rights on account of them being deemed secondary to their male or heterosexual counterparts. We acknowledge, as do several of the papers in this Special Issue, that a burgeoning scholarship on 'intersectionality' and work (Acker, 2012; Bose, 2012; Rodriguez et al., 2016) has the potential to shed important light on how foreign workers, and particularly women and sexual minorities among them, are subjugated to multiple oppressions from established power structures, including those in the host society as well as societies of origin and migrant communities.

To be a foreigner is to have crossed an ethical as well as a geographic border, and hence can lead to bearing social stigma and exclusion. Politically such borders are, in one sense, physical in that they mark out the dividing lines between nation states. That these lines can also separate, inter alia, the rich from the poor, the colonized from the colonizer and the powerful from the subjugated, demonstrates the geopolitical force of the physical border. This politics leads to the question of the ethical status of these borders when they reflect the uneven distribution of power, privilege and opportunity that operates geographically. Moreover, to be a foreigner is often associated with being a stranger, an outlander and an alien, without access to the rights (legally or culturally) granted to locals. To be a foreigner is to be assigned ethically as 'different' and has the potential to confront the locals on the basis of that difference; she is located within a new country but still culturally foreign; she is in between an old home and a new, an outsider risking being an outcast (Bagnoli, 2007). This danger that accompanies this difference is especially pronounced when one's foreignness is located in the postcolonial move from east to west, and south to north where the migration from former colonies to the land of former colonizers brings with it a long and sad history of oppression and exploitation. Nowhere is this more stark than in the long held conflation of control of access to work (Fang et al., 2013), control of migration (Wright, 2014) and control of women's 
bodies (Van Walsum and Spijkerboer, 2007). Clearly, the physical borders that divide up the world operate on a political and ethical level as well as a geographical one.

The ethico-political phenomenon of foreignness as it relates to sex and gender is far from new. In the late 1800s, the Page Act in the United States targeted Asian women migrating for sex work. The act restricted Chinese women from entering the United States by effectively conflating Chinese women's migration with enslaved prostitution (Lubhéid, 2002). Some 100 years later in the 1970s, similar practices were in place in Britain. Government policy stipulated that to enter marriage, a South Asian women had to be a virgin. Enforcing this, British immigration officers subjected prospective Indian brides to virginity tests at the border (Smith and Marmo, 2011). Throughout the 1980 s, immigration regulations in several European countries upheld a gendered division of labour by assigning women a 'dependent' status that kept many migrant women out of paid employment. This was done through family reunification schemes, which assumed that the man was the economically motivated migrant actor, the 'breadwinner' and the woman was his dependent (Morokvasic, 1984). While formal immigration laws have changed, gendered and racialised coding of the labour markets still impacts differently on migrant women. This is most visible in the anti-trafficking policies and the legal category of the 'victim of trafficking', both of which hide women's migratory agency and normalize their exclusion from the labour market (Anderson and Andrijasevic, 2008). Gender, clearly, has long been and remains a central axis of discrimination and oppressions when it comes to migration, work and employment.

The examples cited above illustrate how foreign workers are unequal as concerns employment, legal status, social standing and labour market status. As has long been the case, especially in Western culture, foreigners, slaves, non-heterosexuals and women are excluded from the public space of the polis, deemed not worthy of the same rights as others. This has not been without resistance and important forms of organizing and mobilization have been motivated and carried out by foreign workers. This includes movements aimed at improving working conditions in particular cross-border occupations such as domestic workers (Anderson, 2010), mobilization within global supply chains such as in the garment and apparel industry (Reinecke and Donaghey, 2015), union strategies for mobilizing immigrant and ethnic workers (Erickson et al., 2002; Yu, 2014b), and alternative labour organizations focused on migrant workers (Fine, 2006).

With this background in mind, we developed a call for papers that considered individual differences, context specific experiences and dynamic processes through which the sexed, gendered and classed category of the foreign worker is constructed, enacted and resisted. These interests extended to how the category of the foreign worker might vary historically due to the changes in law, government policy and socio-cultural norms. Of central concern was how such changes influenced work and employment practices, as well as how they are constitutive of workers' subjectivities. The ethico-political implications were especially salient to us in terms of exclusion, discrimination, incorporation as well as resistance and mobilization (Pullen and Rhodes, 2014).

The call for papers was issued with a submission deadline of August 2017, and to enable the development of papers, we convened a stream on the same topic at the 10th International Critical Management Studies (CMS) Conference held by Edge Hill University in Liverpool in July 2017. Our call was responded to by a wide range of scholars from around the world who brought different methodological approaches, and substantive interests to bear on our chosen theme. Kyoung-Hee also convened a stream entitled 'Migration and the Meaning of Inclusion at the European Group for Organization Studies (EGOS)' annual colloquium held a week after CMS in Copenhagen. The result is a set of seven papers whose interests traverse a broad array of international localities and cultural constituencies. In these papers, the problematics of class, race and gender are explored in relation to how foreignness is constructed and enacted in different forms of work including 
automobile, manufacturing, domestic labour, sex work and academic labour from the middle East, to Sweden, to Pakistan, to Nepal, to France and beyond.

In terms of research themes, the papers address the gendered nature of migration (Zulfiqar, this issue; Grossman-Thompson, this issue; Dalton and Jung, this issue), intended and unintended consequences of organizational diversity policy (Romani, Holck, and Risberg, this issue; BacouelJentjens and Yang, this issue), the intersectionality of gender and expatriate status (Rodriguez and Ridgway, this issue), and the performativity of assimilation (Dar, this issue). While we felt that the selected papers represented the micro-politics and the (inter-) subjectivity of being and becoming a migrant as well as intra-organizational politics and inequality structures in an excellent way, we were surprised, if not disappointed, that not enough submissions addressed politics at a societal level and no submitted paper dealt with sexuality and migration. We see these areas as in urgent need of future research.

The Special Issue opens with Ghazal Zulfiqar's 'Dirt, Distance and Foreignness in a Neocolonial Space: Domestic Workers in a Gated Community in Pakistan'. In this article, Zulfiqar studies a residential community within a gated university complex to examine a new urban wage model of domestic labour in Punjab, Pakistan. The author examines how notions of dirt and foreignness are symbolically made use of by the employers, and how militarized surveillance is employed by management to control women workers' bodies and enforce the wage model. This study broadens existing scholarship on domestic work by examining domestic labour arrangements through the lens of a place-specific shifting of social and economic relations, and showing the rise of a depersonalized wage system, which exposes women domestic workers to novel forms of insecurities and vulnerabilities.

The second paper is Barbara Grossman-Thompson's 'Disposability and Gendered Control in Labor Migration: Limiting Women's Mobility Through Cultural and Institutional Norms'. Like the paper that preceded it, a central focus here is on form of power and authority exercised over domestic workers. Grossman Thompson reports on a study with 30 female domestic labourers from Nepal who had worked illegally in the Gulf countries. Drawing on feminist political economy, the institutional logics that shape this workforce are identified as female disposability and gendered control; both of which serve both to reinforce male institutional authority and limit women's mobility.

Third, we have 'Becoming a Cosmopolitan Woman: Rhetoric Versus Reality in the case of Korean sex workers in Australia' by Bronwen Dalton and Kyungja Jung. The authors challenge the dominant media representation of Korean sex workers as poor, as victims of sex trafficking and as a risk to public health. This narrative, they argue, is laced with Orientalist overtones of the Asian sex worker as the alluringly exotic 'other', passive and particularly vulnerable, and in need of rescue. Against the grain, Dalton and Jung highlight how migration based on sex work can be an agentic process of self-expression and self-actualization of identity. They show how the migrant women they studied engage in a transnational quest to become cosmopolitan citizens of the world. In so doing, they were, making logical choices from structurally limited options shaped by their multiple identities as women, sex workers and Koreans, as well as their relatively precarious position in the Australian labour market.

'Benevolent Discrimination: How HR Managers Reproduce Ethnic Discrimination with Diversity Initiatives' by Lawrence Romani, Lotte Holck and Annette Risberg is our fourth paper. The authors investigate how diversity initiatives by a well-meaning HR department in a Swedish manufacturer have paradoxically resulted in what they term benevolent discrimination. They contend that construing minorities as the inferior party in the social relationship in need of assistance as well as expecting them to assimilate into the existing hierarchy both in the organization and in 
the society serves to 'blind' the HR managers to how diversity initiatives result in deepening stratification in the firm.

Jenny Rodriguez and Miranda Ridgway's 'Contextualizing Privilege and Disadvantage: Lessons from Women Expatriates in the Middle East' is the fifth paper. The authors contribute to de-bunking the dominant view of the woman expatriate as privileged by virtue of their skilled and mobile status. They do so by demonstrating how privilege as expatriates and disadvantage as women are intricately inter-connected in the lived experience of women expatriates in the Middle East, and how institutionalized settings maintain a gendered social order by utilizing this duality to circumscribe the rights and responsibilities of women expatriates.

The sixth paper is Sabine Bacouel-Jentjens and Inju Yang's 'Who am I? Different Reactions of Ethnic Minority Groups to an Organisational Diversity Policy'. In this study, focused on a French manufacturing company, the authors explore a tension between the presence of gender affirmative actions and an absence of actions that would address ethnic discrimination within the organization. In France, statistical data tracking of ethnic minority groups of French nationality were indeed prohibited. Bacouel-Jentjens and Yang analyse the effect of the lack of ethnicity-based affirmative action policies on workers, and propose a model that can account for divergent forms of identity construction by minorities within the organization.

The Special Issue closes with Sadhvi Dar's 'The Masque of Blackness: Or, Performing assimilation in the White Academe', a deeply fascinating and unusual piece of creative writing. Taking the title and plotline from the Jacobean masque written by Ben Jonson in 1605, Dar scripts a revisionist play that sets out to consider the politics of assimilation academics of colour perform in their daily lives. Drawing on black liberation and anti-racist literature, the play brings into stark focus how Black and Brown bodies are asked to perform and use voice daringly or silence instrumentally to leverage degrees of assimilation into white structures. 'Diversity', as Dar shows, is a dangerous misnomer in the white academe because the idea fails to recognize the politics of whiteness that structure a spectrum of assimilation academics of colour are positioned by. Through its unusual form and style, the play invites scholars of Organization Studies to experiment with innovative forms of writing that challenge the rigid structures of social science academic writing and the metrics model for assessing research.

Across these diverse contributions, we find that class, race and gender serve to shape a sense of foreignness that is central to the meaning and experience of work. The machinations of power are never far away, as people's differences come to be used as an axis of actual and potential oppression, coercion and exploitation. The collective contribution of the work presented in the Special Issue might well be characterized as the exposition of different ways that such machinations play out in some radically different settings. Much of this is damning; it exposes how women, people of colour and the working class can be rendered both foreign and marginal through practices related to work and its organization, whether that be purposefully or inadvertently. At the same time, however, the contributions to this volume show that migration and migrant labour actively constitute labour markets. Migrant workers are not just the 'object' of managerial control but rather a determinant of how firms organize their operations. In other words, migration shapes organizations' work and employment practices. If anything, this harks a call for the pressing need to continue to trouble, resist and address the ethico-political inequities that arise when it comes to globally mobile labour and to broaden the boundaries of Organization Studies (and its sub-field of CMS in particular) so as to examine in greater detail the connections between migration and subjectivity construction within organizations; migration and emerging models of differentiation, exploitation and unfree labour; and migration and transnational regulation of labour. To sum up, the editors and the authors of this issue urge scholars of Organization Studies to include to greater degree migration perspectives into the study of work and employment, diversity at work, industrial relations and internationalization. 


\section{ORCID ID[GQ: 2]}

Carl Rhodes (iD) https://orcid.org/0000-0002-6571-2872

\section{References}

Acker, J. (2006) 'Inequality Regimes: Gender, Class, and Race in Organizations', Gender \& Society 20(4): 441-64.

Acker, J. (2012) 'Gendered Organisations and Intersectionality: Problems and Possibilities', Equality, Diversity and Inclusion: An International Journal 31(3): 214-24.

Alberti, G., Holgate, J. and Tapia, M. (2013) 'Organising Migrants as Workers or as Migrant Workers? Intersectionality, Trade Unions and Precarious Work', The International Journal of Human Resource Management 24(22): 4132-48.

Anderson, B. (2010) 'Mobilizing Migrants, Making Citizens: Migrant Domestic Workers as Political Agents', Ethnic and Racial Studies 33(1): 60-74.

Anderson, B. and Andrijasevic, R. (2008) 'Sex, slaves and Citizens: The Politics of Anti-trafficking', Soundings: A Journal of Politics and Culture 40: 135-45.

Bagnoli, A. (2007) 'Between Outcast and Outsider: Constructing the Identity of the Foreigner', European Societies 9(1): 23-44.

Bose, C. E. (2012) 'Intersectionality and Global Gender Inequality', Gender \& Society 26(1): 67-72.

Erickson, C. L., Fisk, C. L., Milkman, R., et al. (2002) 'Justice for Janitors in Los Angeles: Lessons from Three Rounds of Negotiations', British Journal of Industrial Relations 40(3): 543-67.

Essers, C. and Benschop, Y. (2007) 'Enterprising Identities: Female Entrepreneurs of Moroccan or Turkish Origin in the Netherlands', Organization Studies 28(1): 49-69.

Essers, C., Benschop, Y. and Doorewaard, H. (2010) 'Female Ethnicity: Understanding Muslim Immigrant Businesswomen in the Netherlands', Gender, Work and Organization 17(3): 320-39.

Fang, T., Samnani, A. K., Novicevic, M. M., et al. (2013) 'Liability-of-Foreignness Effects on Job Success of Immigrant Job Seekers', Journal of World Business 48(1): 98-109.

Fine, J. (2006) Worker Centers: Organizing Communities at the Edge of the Dream. Ithaca, NY: ILR Press/ Cornell University Press.

ILO Labour Migration Branch (2018) ILO Global Estimates on International Migrant Workers. Geneva: International Labour Organization. Retrieved from https:/www.ilo.org/wcmsp5/groups/public/—dgreports/—dcomm/—publ/documents/publication/wcms_652029.pdf

Lubhéid, E. (2002) Entry Denied: Controlling Sexuality at the Border. Minneapolis, MN: University of Minnesota Press.

Morokvasic, M. (1984) 'Birds of Passage Are Also Women', International Migration Review 18: 886-907.

Pullen, A. and Rhodes, C. (2014) 'Corporeal Ethics and the Politics of Resistance in Organizations', Organization 21(6): 782-96.

Reinecke, J. and Donaghey, J. (2015) 'After Rana Plaza: Building Coalitional Power for Labour Rights between Unions and (consumption-Based) Social Movement Organisations', Organization 22(5): $720-40$.

Rodriguez, J. K., Holvino, E., Fletcher, J. K., et al. (2016) 'The Theory and Praxis of Intersectionality in Work and Organisations: Where Do We Go from Here?', Gender, Work and Organization 23(3): 201-22.

Smith, E. and Marmo, M. (2011) 'Uncovering the "virginity Testing” Controversy in the National Archives: The Intersectionality of Discrimination in British Immigration History', Gender \& History 23(1): $147-65$.

United Nations (UN) (2017) 'International Migration Report 2017: Highlights (New York)'. Retrieved from http://www.un.org/en/development/desa/population/migration/index.shtml

Van Walsum, S. and Spijkerboer, T., eds (2007) Women and Immigration Law: New Variations on Classical Feminist Themes. London: Routledge.

Wright, C. F. (2014) 'How Do States Implement Liberal Immigration Policies? Control Signals and Skilled Immigration Reform in Australia', Governance 27(3): 397-421. 
Yu, K. H. (2014a) 'Organizing Immigrants: Meaning Generation in the Community', Work, Employment and Society 28(3): 355-71.

Yu, K. H. (2014b) 'Organizational Contexts for Union Renewal', Relations Industrielles/Industrial Relations 69(3): 501-23.

$\mathrm{Yu}, \mathrm{K} . \mathrm{H}$. (in press) 'Inclusive Unionism: Strategies for Retaining Idealism in the Service Employees International Union', Journal of Industrial Relations, Published online before print August 30, doi: $10.1177 / 0022185618780915$.

\section{Author biographies}

[AQ: 1] 